\title{
ANALISA RELIABILITAS DENGAN METODE DMAIC PADA UNIT EXCAVATOR ZAXIS 450LC-3 DI PT X
}

\author{
Muhammad Ainur Rahman 1), Abdul Ghofur 2), Akhmad Syarief 3) \\ Program Studi Teknik Mesin, Fakultas Teknik Universitas Lambung Mangkurat \\ JL. Akhmad Yani Km.36 Banjarbaru, Kalimantan Selatan,70714 \\ E-mail : muhammadainurrahman1@gmail.com
}

\begin{abstract}
Excavator Zaxis $450 L C-3$ is a heavy equipment used in mining activities. The company that owns the equipment as a powerful engine will be able to carry out the operation or production to the maximum. The cause of disruption Excavator damage that often occurs is the interference with the components on multiple systems. For example undercarriage systems, electric / starting, fuel, lubrication, cooling, air intake / exhaust and so on. Thus it is necessary to study the Analysis of the Reliability Methods DMAIC In Unit Excavator Zaxis 450LC-3 at PT X, so that the operation can continue and to determine the reliability value / reliability of excavator zaxis 450LC-3. The analysis can find out the factors that influence decreasing the reliability of the unit excavator zaxis $450 L C-3$ with the DMAIC method and provide recommendations on the appropriate treatment plan unit zaxis 450LC-3 excavators. Following the analysis of the reliability of the DMAIC method, the reliability of the unit zaxis excavator EX1149, and EX1132 has low reliability. Resulting in lower reliability on zaxis $450 L C$ excavator unit is due to the high frequency of unplanned break down in the system: undercarriage, hydraulic system, cooling system, electric system, and fuel system. Based on the known potential failure, the hydraulic system and engine, then do a treatment plan include: Predictive maintenance, lubrication tasks, corrective maintenance, preventive maintenance and proactive maintenance
\end{abstract}

Keywords: Reliability, DMAIC

\section{PENDAHULUAN}

Nilai keandalan (reliability) dari suatu mesin merupakan ukuran performansi dari suatu sistem. Jika suatu mesin memiliki keandalan yang tinggi, maka probabilitas mesin atau peralatan tersebut mengalami gangguan atau kerusakan akan jarang. Kondisi tersebut akan tercapai jika unit dioperasikansesuai prosedur dan dilakukan pemeliharaan secara periodic [3]. Kehandalan sistem juga harus didukung dengan kehandalan setiap komponen yang membentuk suatu sistem tersebut. Oleh karena itu, peningkatan kehandalan yang berorientasi pada komponen (component-oriented) akan lebih mudah, lebih cepat, dengan pembiyaan yang lebih efektif untuk mengganti komponen atau memperbaikinya, sehingga mesin dapat kembali beroperasi, sedangkan kerusakan pada komponen tersebut dapat diperbaiki untuk selanjutnya digunakan pada peralatan lainnya yang sesuai di masa mendatang. 


\section{TINJAUAN PUSTAKA}

\section{Reliabilitas}

Reliabilitas atau keandalan, adalah konsistensi dari serangkaian pengukuran atau serangkaian alat ukur. Hal tersebut bisa berupa pengukuran dari alat ukur yang sama (tes dengan tes ulang) akan memberikan hasil yang sama, atau untuk pengukuran yang lebih subjektif, apakah dua orang penilai memberikan skor yang mirip (reliabilitas antar penilai) [5].

\section{DMAIC}

DMAIC adalah salah satu prosedur pemecahan masalah yang dipakai secara luas dalam masalah peningkatan kualitas dan perbaikan proses [1] [2]. Terdiri dari beberapa tahapan, yaitu: define, measure, analyze, control

\section{Mechanical Availibility}

Mechanical Availability (MA) adalah suatu metode yang berfungsi sebagai indikator atau pengukuran saja sebagai alat pengukuran mengenai kesediaan atau kesiapan alat berat untuk beroperasi yang mana hasil pengukurannya tersebut dapat dilihat dalam bentuk persentase [6]. Mechanical Availibility dapat dihitung dengan persamaan sebagai berikut:

$$
\mathrm{MA} \%=\frac{\mathrm{OH}}{\mathrm{OH}+\mathrm{DT}} \times 100 \%
$$

Dimana: $\mathrm{OH}$ adalah operating hours (jumlah waktu kerja mesin), sedangkan DT adalah down time (jumlah waktu mesin tidak dapat beroperasi).

\section{Mean Time Between Failure}

Mean Time Between Failure (MTBF) adalah periode waktu rata-rata unit berhenti beroperasi dikarenakan kerusakan [6]. Dapat dihitung menggunakan persamaan sebagai berikut:

\section{Mean Time To Repair}

Mean Time To Repair (MTTR) adalah rata-rata waktu yang diperlukan untuk melakukan perbaikan terhadap terjadinya breakdown suatu unit, sehingga mengembalikan unit dapat kembali beroperasi [6]. Dapat dihitung menggunakan persamaan sebagai berikut:

$$
\text { MTTR }=\frac{\text { Down Time }}{\text { Number Of Failure }}
$$

\section{Failure Mode and Effect Analysis}

failure mode and effect analysis (FMEA) adalah suatu prosedur terstruktur untuk mengidentifikasi dan mencegah sebanyak mungkin mode kegagalan (failure mode). FMEA digunakan untuk mengidentifikasi sumber-sumber dan akar penyebab dari suatu masalah kualitas. Suatu mode kegagalan adalah apa saja yang termasuk dalam kecacatan/kegagalan 
dalam desain, kondisi diluar batas spesifikasi yang telah ditetapkan, atau perubahan dalam produk yang menyebabkan terganggunya fungsi dari produk itu [4].

\section{METODE PENELITIAN}

Penelitian ini dilakukan dengan melakukan pengolahan data berupa data sekunder dengan menggunakan rumus-rumus yang ada. data sekunder yang didapat adalah data kerusakan periode dari bulan januari sampai desember 2014. Dari data tersebut di dapatkan 2 unit Excavator Zaxis 450LC-3 yang memiliki Down Time terbesar, yaitu EX1149, dan EX1132.

\section{Prosedur Penelitian}

Pada tahap define, terlebih dahulu penulis melakukan perhitungan Mechanical Availibility (MA), dan menentukan SIPOC diagram, lalu pada tahap measure, akan dilakukan perhitungan Mean Time Between Failure (MTBF), dan Mean Time To Repair (MTTR), dari perhitungan itu maka akan didapatkan persentase Reliabilitas Unit Excavator Zaxis 450LC-3. Baru kemudian di buat tabel durasi total waktu down time selama 1 tahun untuk 2 unit Excavator Zaxis 450LC-3pada setiap sistemnya. Berdasarkan dari tabel durasi total waktu down time tersebut kemudian pada tahap measure dibuat tabel FMEA (Failure Mode and Effect Analysis) yang mana setelah itu akan menjadi acuan dibuatnya tabel potential failure pada tahap improve. Dan tahap control adalah monitoring serta perencanaan. Dengan menggunakan pendekatan $D M A I C$, hasil yang akan didapatkan adalah berupa persentase nilai Reliabilitas/kehandalan unit Excavator Zaxis $450 L C-3 F$, mengetahui faktor yang mempengaruhi menurunnya Reliabilitas unit Excavator Zaxis 450LC-3F, dan memberikan beberapa rekomendasi rencana Maintenance untuk memperbaiki proses perawatan yang telah ada. Sehingga kedepannya diharapkan Reliabilitas unit Excavator Zaxis 450LC-3 tersebut akan berada pada standar perusahaan yaitu di atas $80 \%$. 